DOI: 10.14526/2070-4798-2019-14-4-8-21

\title{
External linguistics, methods of health-creation, interpersonal interaction in the sphere of sports and adaptive pedagogics
}

\author{
Stanislav V. Dmitriev', Elena V. Bystritskaya ${ }^{1}$, Irina Yu. Burkhanova, Sergey D. \\ Neverkovich ${ }^{2 *}$ \\ ${ }^{1}$ K. Minin State Pedagogical University, Nizhniy Novgorod \\ Nizhniy Novgorod, Russia \\ ORCID: oooo-ooo2-1613-1035, oldladt@mail.ru \\ ORCID: Oooo-ooo2-7954-2341, irina26920o7@yandex.ru \\ ${ }^{2}$ Russian State University of Physical Culture, Sport, Youth and Tourism \\ Moscow, Russia \\ ORCID: , nevercovich@mail.ru*
}

As art, sport and education are philosophically and structurally multidimensional one can find a lot of questions and answers in them, connected with Creation.

M. Kazinik

\begin{abstract}
In order to let education really fulfill the role of social-cultural regulator in the sphere of sports and adaptive pedagogics (S\&AP), it should be directed toward a personality, it should form the culture of human corporality(where "sound mind" is a spiritual base for sound body),it should be directed toward the system of axiological orientations and moral principles. Without cooperation between adaptive pedagogics technologies and a human we can't speak about developing education optimization, methods of health protection and lost functions renewal. It is necessary to teach a human work reflexively-creatively with own consciousness and the mechanisms of bodypsyche, personal and interpersonal health.
\end{abstract}

Keywords: methodology of sports and adaptive pedagogics, interpersonal interaction of education subjects.

For citation: Stanislav V. Dmitriev, Elena V. Bystritskaya, Irina Yu. Burkhanova, Sergey D. Neverkovich*. External linguistics, methods of health-creation, interpersonal interaction in the sphere of sports and adaptive pedagogics. Russian Journal of Physical Education and Sport. 2019; 14(4): 8-18. DOI: 10.14526/2070-4798-2019-14-4-8-21.

Cognitive, body-oriented, regulating methods of developing education in pedagogics.In the article health-creation is considered by us according to three aspects: spiritual (activity organized consciousness broadening), physical (functional-activity based potential realization) and social (active life creation and multifactor adaptation). It means not own potentialities knowing, but also the ability to use these reserves and not revealed potentialities in oneself. In this definition three main personality's structures are shown: cognitive, emotionalemotive and behavioral. We think it is necessary to discuss not the specificity of functional systems ""activity" (it is a biological process), but socialcultural activity of a person in terms of the changing objective environment. We will present only some changes of spiritual-cultural and psychosomatic functions of adaptive pedagogics. It should be taken

into account in professional education of studentsrecreation therapists, psychotherapists, specialists in body-psyche.

Teaching technologies in S\&AP should, in our opinion, include the programs of three types of activity: subject oriented, body oriented and esthetically oriented. Esthetic development of a personality is the ability and need development for reflecting and creating in accordance with subjective parameters of motor activity (morphology, biomechanics, somatic-plasticity, extra-logic programs) and the indicators of human degree (culturological coordinates-values, senses, selforganization of psychicmechanisms). Creativityinthe sphere of artplasticity of movements, imagotherapy (Lat. imago - image) and aesthetotherapy demand serious work of a teacher and a disabled person over subjective content of motor actions (creative expression of the idea by means of "body language"- 
mental-motor heuristic) and a form (artisticaesthetic demonstration of "movements text" visual-motor connotations; mental-motor motilitygesture, mimicry,pantomime).

Aesthetotherapy technologies should provide constructive consciousness transformations (which provide facilitating, healing, adaptive-correcting, aesthetically developing and other effects) and interpersonalinteractions:non-judgementalpositive acceptance of another person, active "empathicmotor understanding" (mutual "artistic experience" of expressive plastic images of movements) and extralinguistic congruent (adequate, real and sincere) self-actualization in communication with him (including the language of "movements semantics").Thus, arttherapeutic technologies, which reflect "meta individual existance" of a person - his "reflection" in another personality, creative-motor "semantic dialogue" of two or more sovereign subjects of educational-teaching process. These technologies not only reflect "universal set of communication", but also are able to form, develop catathymic-emotional sphere of a personality (expressive response in a soul-aesthetic catharsis), intellectual sphere of a person (creative abilities), body-psychic sphere of motor action subject ("mental-corporal extralogic consciousness").Here notional congruency (from the word "congruentis"corresponding, coinciding) is very important correspondence between what a person understands verbally and body language ("body image", "corporal Self") and the structures (mechanisms) of bodyconsciousness (consciousness métaphorisation, semantic ideomotion, artplasticity, imagotherapy). Corporal-notional congruentis is "artistic-aesthetic experience" incursion into notional-motor sphere; "sense-knowledge" means into the sphere of notional action organization; emotions and creative imagination into the sphere of corporal intellect [210]. Anthropic technologies need the mechanisms creation of so called janusian thinking [1] the abilities of a person to consider simultaneously two opposite points of view (Janus - ancient Roman idol with two faces, looking opposite sides).

We can speak about "interaction" of differently organized in content and form ideas (ideas-actions, ideas-knowledge), which "directly influence" the object/subject of the thought. So, for example, a disabled person "playing, learns" (the orientation of activity on process dominates) and "learns, playing" (the orientation of the activity on the result dominates). In spectacular programs of teaching the process of creativity should dominate over the result. The achieved result is only an instrument, the way of development, one of the necessary means of autotherapy (Gr.autosmeans “oneself”). It is necessary to find the points of support in oneself for creative personality development and improvement. In motivational sphere of a person not the desire to be "like others" should dominate, but a complete self-actualization of abilities, which form mentalmotor potential of individuality. Unfortunately, the problem of the playing ratio (in genewal), autotheraputic and educational development in S\&AP didn't get scientific-methodical analysis.

Modern literary criticism considers a reader's attitude to the author as a dialogue, interview, meeting [10]. So the message that the author wants to transfer to the reader, author's definite "program of influence" on "the imaginary reader" turns out to be the product of different social-cultural discourses: intention of the addresser (expressive text), creative experience of the addressee (impressive text), context of perception (codes, active in this culture, social and cultural mindsets, language references, axiological- notional systems of a personality, emotional-expressive transaction). For example, during "movements text" perception a person's eidetic abilities to "see in imagination" the semantics of motor actions are important ("reading by images, not by words"). With the help of the motor identification mechanisms we create "a vivid image" of motor actions, which has a lot of variants, each of which not always can be identified by a word (the mechanism of perception psycho-semantics of ballet dancer's, aerobics coach's, conductor's movements is similar to the way of "understanding without words").

In essence organization of "live texts" there is a difficult coordination between biological programs. It characterize individual heredity (bio code), and over-biological programs of behavior, communication and activity. It form "social-cultural heredity" (social code). It should be noted that in a 
dialogue between a person and a world by means of "live text" world is revealed in the text in a set discursiveness. It is realized and re-considered in it. Very often there appears a kind of "concept glaze" of the object, when one layer of the essence is seen through the other layer (concept superposition). It is known that the essence of this or that object understanding is not the deepest level of its understanding. The future research workers, as a rule, understand a literature source better, than its authors and contemporaries ("F.Schleiermacher paradox"-the founder of early Hermeneutics). It is connected with the fact that during the process of essence realization not only text and its author are activated (any author is the son of own epoch), but also the connections of text context and the tendencies of social development, which can be unknown to the author.

It is known that objectness of a person's "live movements" are always material, it can have spiritual character. We separate the notions of subjectness(inner world of consciousness) and subjectivity (individual's point of view, which is very often doesn't correspond with the points of view of other people or which contradicts with the results of science).Different people can have one subject of activity (the subject of cognition, estimation and transformation). The aspects of its interpretation are mutually complement and the ways of "personal ascension" to it are different and individual. During the process of extralogic mental, artistic and creative-motor objectives solution a person "creates himself"- not only "becomes educated"(gains knowledge, skills and competencies), but also transforms his axiologicalconceptual world himself: own understanding, own point of view, own attitude to the situation of the objective and activity interpretation. In educational technologies the methods of subjective reflection are very important. With the help of these methods the subject of education acts in accordance with "logic of the object" and in accordance with "logic of notions": here, in the opinion of French mathematician and philosopher A. Poincare, the intuition creates and logic proves. At the same time, a person's involvement into the process of activity is realized. This is an ecstatic process, which "catches" emotions, thoughts and actions of activity subject. A musician "sinks" into music; poems "penetrate" into a poet or a reader; an athlete has "muscle joy of movements", starts "to think with his whole body" (the phenomenon of "intellective cloth made of mixed yarn" appears- the language of hybrid, polymodel, extralogic thinking).

It is known that essence interpretation is a transformation of the mastered by person concepts in accordance with his conceptual-axiological system. If "understanding" reality by a person provides, first of all, the procedure of generally important essence formation and revelation ("penetration" into conceptual structure of knowledge and "inner" logic of its development revelation), the term "extralogic interpretation" is oriented toward the procedures of texts, phenomena and facts of science, culture and activity interpretation (conditioned by personal expectations and intentions of the "interpretant"). "Interpretant" gains relevant information in accordance with his own needs and axiologicalnotional mindsets. For example, theatre spectator in "the dialogue of perception and interpretation" sees acting area of Khlopusha monologue in "Pugachev" play "with the eyes of Vladimir Vysotskiy". Interpreting other worlds, "entering" the space of society, culture and own world of view, the acting personality forms herself, forms own individuality.

It should be noted that in theatre-artistic system K.S. Stanislavskiy an actor is offered to enter inner world of his character, imagine himself in the body of a character, overcome "the border of Self-sense" (V.A.Podoroga), "energetic border" (L. Marchel), "contact border" (F. Perls), "border of manysidedness" (A.Sh. Tkhostov). As a result there is both "live movement" and thought-action diversification and inner space of the personality, the ability development to realize authentic selfactualization and provides social-cultural programs mastering. Any creative-motor action /thoughtaction of a person "is covered" by the spirit of the Creator and the latter has the opportunity to enjoy the process of "covering" - he is happy because the sense of his authentic character. We come to the conclusion that in adaptive physical culture (APC) methodology the methods of "deep ecology of a personality" (A.Neuss), "muscle joy" (I.M. 
Sechenov, I.P. Pavlov), “corporal-motor happiness" of a person, are conditioned not only by the mechanisms of interiorization (P. Janet, J. Piaget, H.Wallon, P.Ya. Galperin) are important. It is known that no "exogenous factors" can guarantee real happiness of a person. The methods of implication, involvement into communication with other people, the mechanisms of catathymic-motor catharsis, "involvement", "engagement" into the process of creative activity (M.Csiksentihalyi).Catathymicmotor "corporality, felt inside", "emotionally- mental models of a personality", unfortunately, are not used in educational technologies in the sports and adaptive pedagogics sphere. We try to present categorical aspects for the mentioned drawbacks elimination (pictures 1, 2).

As underlined Austrian-English philosopher L. Wittgenstein, "the borders of my language mean the borders of my world", experienced and transformed in this or that way - personality oriented- situation of subjective activity.

\section{Conceptualprinciplesofascientist-research worker, constructor and educational technologist}

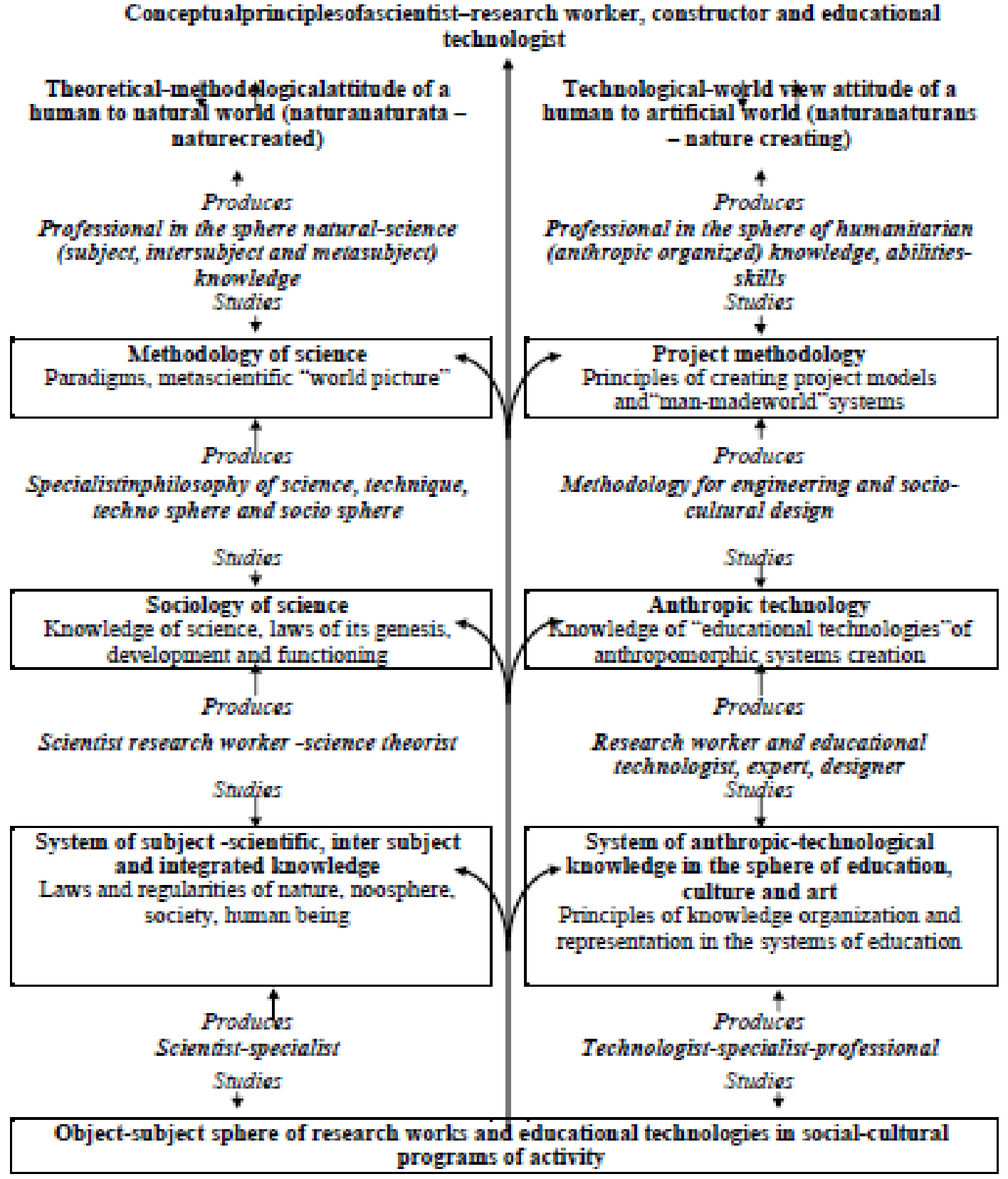

Pic.1. Social-culnural projection of educational space and educational environment of a higher echucational establishment (read below) 


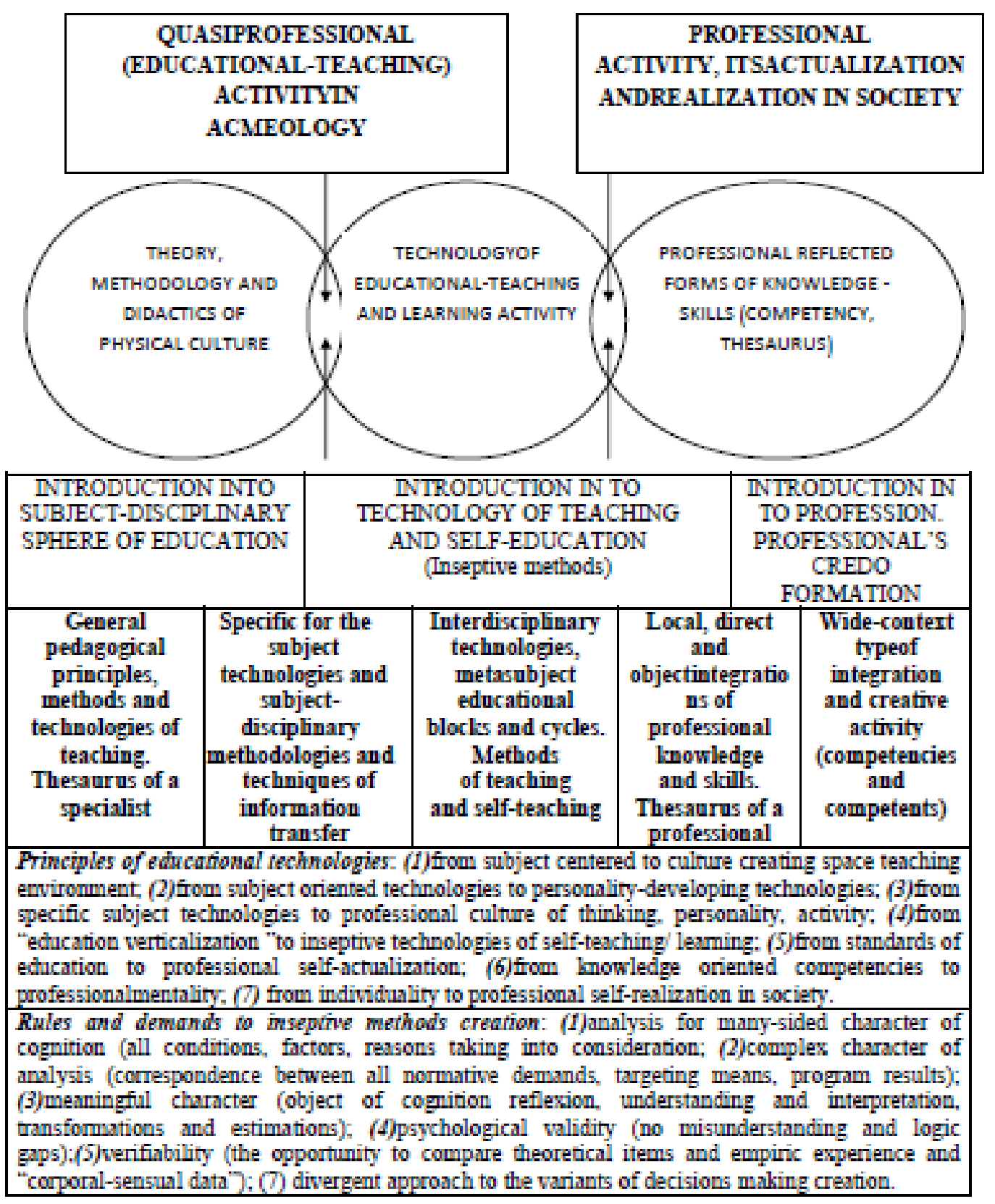

Pic.2. Educational-teaching systems - multilevel in structure, multifunctional according to aims

In sports and adaptive pedagogics by means of "body language" choreographers, athletes of artistic kinds of sport, moderators of education (who provide involvement into the process of qualification improvement the subjects of education, organized in a form of "educating research" and "studying teaching"[5]) try to reveal inner depths of own "psychosphere" - they "adore the world" and at the same time "adore themselves" in their innovativecreative actions.

Adancer-moderator, for example, feels "music in body", thinks with the help of the language of movements, opens new opportunities of own "live body". The culture of corporality, culture of movements and culture of human spirit form a kind of semantic-motor continuum - depending on the situation of the solved objectives and strategies of activity. M. Plisetskaya had different variants of "dancing music" (she didn't "dance to the music"), in particular, duringdancing the role of "Dying swan". If violins dominated, the movements of the ballet dancer were more "tragic", than in the situation, 
when accompanied Y.Bashmet. In the composition, performed together with opera singer Montserrat Cabalier, the song of a dying swan «dominated», the voice of a singer "was leading" the dance.

The art plasticity of movements among violin players Akkiko Suvandi (Japanese school of performance) and Vanessa Mae (Korean musician) is different. Both "merged" into the instrument, both have constant mimicry ad pantomimicry steps, bends, turns of the spine, body straightening. At the same time, we can mention that the base of movements of Akkiko forms "emotional-practical intellect" (natural conjugation-contamination-body movements, emotions and the produced sounds). In the performance by V. Mae dominates "image text of movements", connected with "public posturing".

It is known that artistic-notional perception of "social-cultural composition" depends not only on "the picture itself", but on the way we look at it. Peripheral type of vision is based on scanning (panoramic) perception, mechanisms of central vision perceive the details (local-step-type). For example, if we look into the eyes of Mona Lisa (picture by Lionardo da Vinci "Gioconda") or at its background behind her shoulders, peripheral type of vision "starts to work". The woman's smile seems to be more distinct, because this type of vision defines the play of light and shadows and colors. If we look directly at the lips of Gioconda, a famous multilevel (extralogic) smile is almost not seen, as the brain studies the details, but doesn't define the tones and shades. And finally, the smile disappears, if we stare at Gioconda. The problem of education is in the problem how anthropic technologies are used, how function didactic mechanisms in the system of teaching. It is clear that we only started to create difficult interdisciplinary sphere, which borders with the language, activity, notion and consciousness and social structures.

It should be noted that in the traditional methodology there is education in a narrow sense and teaching - transfer and mastering some volume of knowledge and skills in a chosen sphere. Moreover, there is education in a wide sense, which includes together with "education of a personality" and "teaching activity" also a person's development, his professional training and personality's upbringing. Teaching is a process of mastering (mastering in activity and for activity) new norms, methods and technologies. It define the level of involvement into culture, traditions, achievements of a society (including the sphere of science, art, sport, production). It is known that the term "teaching" is considered as "outercreated", outer defined process; term "education" includes both the process (mainly psychic) and its result (the production of personally formed product). Upbringing is the process of controlling own needs (needs enculturation) by a subject. This process defines the level of spiritual-activity based (axiological) personality's consciousness, way of life and professional activity. Development is the spectrum (structural interaction) of intellectual and psycho-physical abilities of a human widening. It should be noted that the increase of potential is not development. Real development is the process of skills improvement (skills enculturation) by means social cultural actions improvement, using the methods and ways of professional activity. It define the level of many-sided (different-sided) functioning human-doer in society. In adaptive physical culture technologies we form not only a disabled educated student (who is adapted to environment), we form a personality, which is able to study, making stress on corporal formed ability (as the feature of a personality) and personal development (needs, abilities, self-development, world view).

In ontodidactics there are different points of view concerning social-cultural personality development: 1) teaching is development (J. Watson); 2) "teaching goes after development" (W. Stern); 3) development doesn't depend on teaching (J. Piaget); 4) teaching goes before development (L.S.Vygotskiy). We suppose that teaching, anticipating development, stimulates it and should be based on the mechanisms of actual development, but not developing what is "set in genetic programs". It is known that in Physical culture and adaptive physical culture the term "training standard"corresponds with the notion "learning capability". Training standard is a result of the previous teaching. Learning capability is the ability of a person to realize further development.

Nowadays corporal-plastic methods of 
prevention, bearing formation and correction and locomotor apparatus injuries (bone tuberculosis, rachitis, infantile cerebral paralysis) prevention are created in rehabilitation biomechanics and kinesitherapy (which correct somatic psychic dysfunctions), the techniques of deep breathing in special positions are used. Created by us theoretical and practical approaches can be used for different poses formation and correction not only in coordinates (topographical orientation) of body (lying, sitting, standing, in different hanging positions), but also in coordinates of corporal plastic movements in subject environment of activity and extrapersonal space of a personality. In kindergarten a teacher should communicate with children "standing on the knees" (play together with then on the floor). Here we see not only "knowledgeskills transfer", but also "minds meeting", not correcting corporal-psychic functions and not soul healing, but the process of "healing with soul". Here special status is given to psychotherapy of mutual-enriching communication, body-oriented therapy, activity based-notional catharsis and other anthropic technologies, "functioning" on the bound of psychic-mental and spiritual.

A teacher-instructor should have a planscheme for each disabled person (a project, a program, a scenario). A plan of psychologicalbiomechanical rehabilitation, according to each course of correction and movements and locomotor apparatus adaptation. The separate components of correction system of creative-motor actions are realized by us using the methods of cognitive control (in terms of different "breaking" artplastics movements), perceptive-motor processes control (suigeneric), the ways of artistic-aesthetic actions and their results, emotional-linguistic control. During the methods of aesthetic therapy and artplastics creation emotional intellect is important. This intellect is demonstrated in senses and emotions perception, control, understanding and estimation. A person with individuality percepts emotionally important factors (gestures, mimicry, "eye contact", touching the partner) and emotionally loaded results of both individual and mutual activity. It should be noted that a disabled child, "inner directed", acts in accordance with "notional gyroscope", which is inside his personal sphere. A child, "guided by others", has a "notional radar" inside, which reacts at values and demands of society.

Thus, if we acknowledge corporal plasticity as biomechanical category, it opens subjectdisciplinary space of pedagogical kinesiology in the sphere of art, theatre, sport and adaptive physical culture. The system of used by us notions in spectacular studio of dancing-motor and arttherapeutic technologies broadens students' "mental-motor experience" at the corresponding higher educational establishments (athletes of different class), broadens their "corporal selfactualization" and "body experience".Artplastic technologies, methods of imago and aesthetic therapy provide the following notional operators creation: "body schemes" (with the defects of locomotor apparatus), "schemes of orientation" (orienting associations), "schemes of action" (mind project and program), modal "movements language". The mentioned "figurative schemes" form so called identification matrixes, on the basis of which the existing and gained "knowledge-abilitiesskills-competencies" become regulated. The most important objective of a teacher-technologist in the sphere of spectacular programs is to teach students adequately transfer theoretical and cultorological basis of art, considered in western and eastern educational technologies, into psychological mechanisms of aesthetic and artistic creativity (imagination, inspiration), including the methods of educational personality and activity of a disabled person development.

In our opinion, we shouldn't strictly oppose eastern and western culture of thinking and a person's consciousness, as these are cultures of humanity as an integrated kind. That is why when we say "West", "East", "western culture", "eastern culture" and underline the existing differences, we are right only till the definite moment. In sports activity technique and technology this difference (S.V. Kalmykov, A.S. Sagaleev and other authors) is quite clear (table). A reader, undoubtedly, will see a rational sense in Eurasian concept, which should be taken into account, thinking over the situation in Russia, realizing practical educational system reformation in the physical culture sphere. 
Table -Eastern and western mentality of a personality and athletes' activity in professional-axiological systems of hand-to-hand fighting (S.V. Kalmykov, A.S. Sagaleev)

\begin{tabular}{|l|l|}
\hline $\begin{array}{l}\text { EASTERN MENTALITY OF PERSONALITY, } \\
\text { THINKING AND ACTIVITY }\end{array}$ & $\begin{array}{l}\text { WESTERN MENTALITYOFAPERSONALITY, } \\
\text { THINKING AND ACTIVITY }\end{array}$ \\
\hline $\begin{array}{l}\text { Overcoming attachment to individual Self", } \\
\text { merging into collective (collective archetype of } \\
\text { consciousness, according to C.Jung ) }\end{array}$ & $\begin{array}{l}\text { Psychic and social-cultural activity connection } \\
\text { with individual "Self" }\end{array}$ \\
\hline $\begin{array}{l}\text { To be beyond the scope of verbal structures, the } \\
\text { absence of the realized motivation ("Super-Self" } \\
\text { fulfills the action, according to S. Freud) }\end{array}$ & $\begin{array}{l}\text { Verbal-indicative motivation of the action ("I" } \\
\text { fulfill the action) }\end{array}$ \\
\hline $\begin{array}{l}\text { Intuitive information- implicit and not realized } \\
\text { knowledge (orientation toward how to do, but not } \\
\text { toward what to do) }\end{array}$ & $\begin{array}{l}\text { Rational and reflexive realized knowledge, based } \\
\text { on project-motor experience and mental-motor } \\
\text { heuristics }\end{array}$ \\
\hline $\begin{array}{l}\text { Continuity of upbringing and thinking ("continuous } \\
\text { diversity» of the processed information) }\end{array}$ & $\begin{array}{l}\text { Discreetness of perception and thought } \\
\text { (separate, discontinuous, independent) }\end{array}$ \\
\hline $\begin{array}{l}\text { Unity of a human and nature, synthesis of micro- } \\
\text { and macrocosmic, informational and energetic }\end{array}$ & $\begin{array}{l}\text { A human opposed to nature ("human is over the } \\
\text { nature") }\end{array}$ \\
\hline $\begin{array}{l}\text { "Rest in movement", "non-action" ("action- } \\
\text { through-non-action»), compliance, wait-and-see } \\
\text { approach, impassibility }\end{array}$ & $\begin{array}{l}\text { Activity, control over actions, purposefulness } \\
\text { and will, emotionality and aggression }\end{array}$ \\
\hline $\begin{array}{l}\text { Image-sensual (mental) perception ("sense- } \\
\text { knowledge"), corporal-psychic action organization }\end{array}$ & $\begin{array}{l}\text { Discursive -logic thinking, formal-logic } \\
\text { knowledge and actions organization }\end{array}$ \\
\hline $\begin{array}{l}\text { Technical-tactical actions present triunity of } \\
\text { physical body, information-controlling model } \\
\text { of consciousness and energy exchange with } \\
\text { environment }\end{array}$ & $\begin{array}{l}\text { The actions of a human are fulfilled in } \\
\text { accordance with biophysical laws of "live } \\
\text { mechanism" functioning. }\end{array}$ \\
\hline $\begin{array}{l}\text { soul, which is the part of World Intellect is typical. } \\
\text { inside) Metaphysical understanding of indidual }\end{array}$ & $\begin{array}{l}\text { Western thinking is extravert thinking } \\
\text { (directed outside). For it «mind» (soul) lost its } \\
\text { individual's mentality functioning. }\end{array}$ \\
\hline
\end{tabular}

In educational technologies it is difficult to master culture of human corporality (body canon), culture of human movements (artplasticity), culture of human mentality (thinking-knowledge). One of platonico dialogues ends with the sentence, which turned into a proverb: "Beauty is difficult". This proverb is polysemantic. What is the object of understanding and interpretation in a hand-made work: the object itself or its author? the idea of the author or "spirit" implied into the text? "the spirit of the work" or "the spirit of epoch"? What did the author want to say (the idea of the work) and what had been said (semantic content of the work)? Do people think with the help of language or thoughts? What is more important for a language: to be the means of communication or to be the means of idea realization? What is more important for the recipient: to understand the language of the work or to understand the idea of the author? We showed that (S.V.Dmitriev [1, 11]), "the formed thought-knowledge" of a cognitive-motor subject is an epistemological category. It underlines the 
ratio of thinking, knowledge and development as three forms of intellectual activity and the ways of their interaction. An important aim of held by us research works is deep analysis of "notions and relations algebra" sphere in subject-activity based reflexion (comprehension) of the World. The traditional plane "subject-object", "language personality-language consciousness", "thoughtimage" (where each member of opposition has an independent meaning) is changed by the sphere of extensional panchronistic space (from Greek pan- all; the first part of complicated words, which means "all covering", "in general"). The object of cognition in this case is not "pasted together" from "two sides of one medal", but the integral one, as "notional space". At the same time, the object of analysis-synthesis can be "turned around" "another conceptual axis", depending on which on its "outer" or "inner" space in different forms we see "notional formations" ("clouds of notions", connected with thinking and activity-based consciousness). We revealed that creatively thinking person not always can define himself, what he "reads" from the objects of cognition and what he "implies" into it (the function of essence creation).

As we see, dialectics of notional interpretation of this or that text is difficult. During interpretation a kind of "hermeneutic dialogue" is realized with the results of another person's activity (society in general). In terms of science or education it means that this or that problem reconstruction. No man can avoid psychological tension, "pre-understanding" of the problem, defined by the level of his knowledge, aims, values, borders of "life world", language consciousness, mindsets of a personality. It should be noted that "the world of the author", though is opened in the text in a set discursiveness (logic of his thinking), but at the same time, it is reconsidered from the positions of a reader. A theatre-goer sees "with the eyes of Hamlet" and at the same time, he sees Hamlet with own eyes (two positions in "the dialogue of perception”). This system combination (polylogue, extralinguistic position) is a "seamless chiton", which is the sphere of semantic-synthetic personal knowledge/ thoughts-knowledge. These are "conceptual syntagmas" (from Greek syntagma "built together, combined"), based on a system unity, built through co-development of different things, but not through emerging into the same context. This sphere of consciousness of a thinking and acting person, the components of which can be separated only with the help of abstraction and only for their detailed analysis ("united Self" and "multiplex Self"). For example, "the thought of a sense" (senseknowledge) is impossible to transfer (without "escaping balance") into "thought of intellect". They are accumulated on one another, forming "the unity of totality". Here at least two different ways of reality reflexion are used simultaneously. In terms of one way the systems of discreet events coding are used and linear chains of segments are formed, each of which has its own meaning. In terms of other way of reflexion continual system prevails, "its essence is organized not with linear, non-time succession, but it is spread in p-dimensional semantic space" (Y.M. Lotman).

In pedagogical kinesiology new paradigms are demanded. They help to study the unity of soul, body, intellect and activity-based consciousness not according to the principle of alternativeness, but according to the principle of complementarity (in accordance with views of N. Bohr). It would help to combine in theory of social-cultural motor actions two plans of human existence - Substance and Spirit, "corporal body" and "Self-consciousness", «menssana in corporesano" ("sound mind in a sound body" according to D. Iuvenalis).

\section{CONCLUSION}

It is difficult for students of special higher educational establishments to grasp the essence of these or that notions in theory, in methodology of teaching motor actions. How to choose the criteria of beauty, harmony, ideal, unique for such different objects, as body, corporal-psychic health of a person and artplasticity of his movements, aesthete therapy and design-projects of subject environment of activity. There is inorganic nature (rainbow, stars, mountains) and highly spiritual works of art (painting, music, sculpture). Where can general features, objective standards in science, art, educational sphere be found? Perhaps the most important principle of scientific, art and educational technologies is in maximum effect achievement in 
terms of minimal means - mathematical proof, technical rationality of movements, mental-spiritual construction. It appears during harmonious "mutual reflection" (mutual understanding, empathy) of sovereign subjects of activity? There is no final answer in science and system of education.

In conclusion it should be noted that in educational activity, in contrast to scientificcognitive or productive activity, its objectives solution should correspond not only with the aims of activity, but also with world view positions, methods and means (pedagogical credo, professional mentality, metacognitive extrologic strategies). These anthropic technologies, being included into subject content of education/teaching/development and into relationship environment (into which a person is involved as a subject), first become the subject of corresponding information mastering. Then, being mastered in subject-tool actions, become the methods and means of interdisciplinary (scientific, technological, productive). These technologies turn out to be implicative, where merge the ideas, hypothetical thinking, heuristic search, artplasticity and somatic-aesthetics of movements, possible world reflection, self-opening in the world and inner world in oneself.

\section{REFERENCES}

1. Gagin Yu.A., Dmitriev S.V. Duhovnyj akmeizm biomehaniki [Spiritual acmeism of biomechanics]. Saint-Petersburg: Baltic pedagogical academy publishing house. 2000: 398 (In Russ.).

2. Delez Zh. Logika smysla [Logic of essence]. Moscow: "Academy” publishing center. 1998: 472.

3. Dmitriev S.V., Voronin D.I., Kuznetsov V.A. Obuchenie dvigatel'nym dejstviyam studentov fakul'teta fizicheskoj kul'tury: teoriya, tehnologiya, innovacionnoe pedagogicheskoe modelirovanie [Teaching motor actions among physical culture faculty students: theory, technology, innovative pedagogical modeling]. Manual for teachers, postgraduates and students. N. Novgorod: Novgorod State Pedagogical University. 2009: 43. (In Russ.)

4. Dmitriev S.V., Neverkovich S.D., Bystritskaya E.V. Dialogue and co-creation in educational process. Mir psihologii. 2011; 2(66): 175-181 (In Russ.).

5.Dmitriev S.V., Neverkovich S.D., Bystritskaya E.V. Educational technology of professional activity subject formation. Sportivnyj psiholog. 2011; 3(24): 14-22 (In Russ.).
6.Dmitriev S. V., Neverkovich S.D., Bystritskaya E.V.,Voronin D.I. Transversalprograms for the system of teaching undergraduates in the sphere of physical culture. Part 1: docendodiscimus (teaching others, we learn ourselves). Sportivnyj psiholog. 2014; 3: 15-19 (In Russ.).

7.Dmitriev S. V., Neverkovich S.D., Bystritskaya E.V., Voronin D.I. Transversal programs for the system of teaching undergraduates in the sphere of physical culture. Part 2: Presumption of culture in anthropic technologies of education. Sportivnyj psiholog. 2014; 4: 17-22 (In Russ.).

8.Dmitriev S. V., Bystritskaya E.V. Formirovanie soznaniya I samosoznaniya studentov na osnove predmetno-smyslovogo soderzhaniya obrazovatel'nyh tehnologij [Consciousness formation and self-consciousness of students on the basis of subject-conceptual content of educational technologies]. N. Novgorod: Novgorod State Pedagogical University. 2012: 286 (In Russ.).

9. Dmitriev S. V., Neverkovich S.D., Bystritskaya E.V., Voronin D.I. Anthropoconstructs of self-consciousness, thinking and a person's activity in the sphere of educational technologies. Mir psihologii. 2012; 2: 209-222 (In Russ.).

10. Dmitriev S.V., Neverkovich S.D., Bystritskaya E.V. School of perception, constructive thinking and productive action of an athlete in the methodology of psychological-pedagogical teaching. Teoriya I praktika fizicheskoj kul'tury = Theory and practice of physical culture. 2013; 5: 96-102 (In Russ., In Engl.).

11. Dmitriev S.V., Neverkovich S.D., Bystritskaya E.V., Voronin D.I. Semantic space of "live movements" in the sphere of language consciousness and self-consciousness of a person as a creative personality. Mir psihologii. 2014; 3: 173186 (In Russ.).

12. Dmitriev S.V. Ontodidaktika obrazovatel'nyh tehnologij na osnove sociokul'turnoj teorii dvigatel'nyh dejstvij cheloveka: sport, iskusstvo, lichnostnoe razvitie sub'ektov obrazovaniya [Ontodydactics of educational technologies on the basis of socialcultural theory of a person's motor actions: sport, art, personal development of the subjects of education]. Monograph. Moscow: "Prometheus" publishing house. 2019: 445 (In Russ.).

Evseev S.P. Teoriya $i$ organizaciya adaptivnoj fizicheskoj kul'tury: uchebnik [Theory and organization of adaptive physical culture: textbook]. Moscow: Soviet sport. 2003: 448 (In Russ.).

13. Armstrong N., Welsman J.R. The physical activity patterns of European youth with reference to methods of assessment. Sports Medicine. 2006; 36: 1067-1086. 
14. Craig C.L., Marshall A.L., Sjostrom M., Bauman A.E., Booth M.L., Ainsworth B.E. et al. International physical activity questionnaire: 12-country reliability and validity. Medicine and Sciences in Sports and Exercise. 2003; 35: 13811395 .

15. Esculcas C., Mota J. Physical activity and leisure behaviors in adolescents: The influence of physical activity characteristics and socio-economic status. International Journal of Behavioral Medicine. 2000; 7: 208-213.

16. Sirard J.R., Melanson E.L., Li L., Freedson P.S. Field evaluation of the Computer Science and Applications, Inc. physical activity monitor. Medicine and Sciences in Sports and Exercise. 2000; 32: 695-700.

\section{Submitted: 13.11.2019}

\section{Author's information:}

Stanislav V. Dmitriev - Doctor of Pedagogics, Professor, K. Minin State Pedagogical University, Nizhniy Novgorod, 6030oo, Russia, Nizhniy Novgorod, Ulyanov str., House 1, e-mail: stas@mts-nn.ru Elena V. Bystritskaya - Doctor of Pedagogics, Professor, K. Minin State Pedagogical University, Nizhniy Novgorod, 603ooo, Russia, Nizhniy Novgorod, Ulyanov str., House 1, e-mail: oldlady@mail.ru Irina Yu. Burkhanova - Candidate of Pedagogics, Associate Professor K. Minin State Pedagogical University, Nizhniy Novgorod, 6030oo, Russia, Nizhniy Novgorod, Ulyanov str., House 1, e-mail: irina2692007@yandex.ru

Sergey D. Neverkovich - Professor of GCOLIFK, Doctor of pedagogics, Member of the Russian Academy of Education, Russian State University of Physical Culture, Sport, Youth and Tourism, 105122, Russia, Moscow, Sirenevyj bulvar, House 4, e-mail: neverkovich@mail.ru 